\title{
Effect of kisspeptin on in vitro maturation of sheep oocytes
}

\author{
Priyanka Byri ${ }^{1}$, Arunakumari Gangineni ${ }^{2}$, K. Ramachandra Reddy ${ }^{2}$ and K. B. P. Raghavender ${ }^{3}$ \\ 1. Department of Veterinary Gynaecology and Obstetrics, College of Veterinary Science, P.V. Narasimha Rao, Telangana \\ Veterinary University, Rajendra Nagar, Telangana, India; 2. Department of Veterinary Gynaecology and Obstetrics, \\ College of Veterinary Science, P.V. Narasimha Rao, Telangana Veterinary University, Korutla, Telangana, India; \\ 3. Department of Veterinary Surgery and Radiology, College of Veterinary Science, P.V. Narasimha Rao, Telangana \\ Veterinary University, Rajendra Nagar, Hyderabad, India. \\ Corresponding author: Arunakumari Gangineni, e-mail: aruna.gangineni@gmail.com, \\ Co-authors: PB: priyankabyri@gmail.com, KRR: krcreddy_scientist@yahoo.co.in, KBPR: drkbpr@gmail.com \\ Received: 09-10-2016, Accepted: 31-01-2017, Published online: 04-03-2017
}

doi: 10.14202/vetworld.2017.276-280 How to cite this article: Byri P, Gangineni A, Reddy KR, Raghavender KBP (2017) Effect of kisspeptin on in vitro maturation of sheep oocytes, Veterinary World, 10(3): 276-280.

\begin{abstract}
Aim: The aim of this study was to investigate the effect of kisspeptin (KP) on in vitro maturation (IVM) of sheep oocytes aspirated from the ovaries collected from slaughterhouse.

Materials and Methods: Two different experiments were conducted to investigate the effect of KP $(5,10$ and $15 \mu \mathrm{g} / \mathrm{ml}) \mathrm{alone}$ (experiment 1) or in combination with follicle-stimulating hormone (FSH), luteinizing hormone (LH), and Estradiol ( $\left.\mathrm{E}_{2}\right)$ (experiment 2) on IVM of sheep oocytes. Tissue culture medium 199 supplemented with Gentamicin was used as control medium. Good quality oocytes were randomly allocated into different IVM media and cultured at $38.5^{\circ} \mathrm{C}$ in $5 \%$ $\mathrm{CO}_{2}$ under humidified atmosphere for $24 \mathrm{~h}$. The oocytes were evaluated for their cumulus cell expansion (CCE) and extrusion of the $1^{\text {st }}$ polar body $(\mathrm{PB})$ at the end of maturation.

Results: The proportion of oocytes showing CCE and extrusion of PB was highest when the oocytes were matured in the medium supplemented with $10 \mu \mathrm{g} / \mathrm{ml}$ of KP. In experiment 2, oocytes were matured in 12 different maturation media $\left(\mathrm{G}_{1}-\mathrm{G}_{12}: \mathrm{G}_{1}\right.$ : Control, $\mathrm{G}_{2}: \mathrm{KP}$ alone, $\mathrm{G}_{3}: F S H, \mathrm{G}_{4}: F S H+K P, \mathrm{G}_{5}: \mathrm{LH}, \mathrm{G}_{6}: \mathrm{LH}+\mathrm{KP}, \mathrm{G}_{7}: \mathrm{E}_{2}, \mathrm{G}_{8}: \mathrm{E}_{2}+\mathrm{KP}, \mathrm{G}_{9}: \mathrm{FSH}+\mathrm{LH}+\mathrm{E}_{2}$, $\mathrm{G}_{10}: \mathrm{FSH}+\mathrm{LH}+\mathrm{E}_{2}+\mathrm{KP}, \mathrm{G}_{11}: \mathrm{FSH}+\mathrm{LH}+\mathrm{E} 2+$ fetal bovine serum (FBS), $\left.\mathrm{G}_{12}: \mathrm{FSH}+\mathrm{LH}+\mathrm{E}_{2}+\mathrm{FBS}+\mathrm{KP}\right)$. The proportion of oocytes showing cumulus expansion and PB extrusion was highest (98.33 \pm 1.05 and 89.17 \pm 2.38 ) when they were matured in $\mathrm{FSH}+\mathrm{LH}+\mathrm{E}_{2}+\mathrm{FBS}+\mathrm{KP}\left(\mathrm{G}_{12}\right)$ and was significantly higher than other groups. The proportion of CCE and extrusion of PB was significantly increased when $\mathrm{KP}$ was supplemented to $\mathrm{FSH}$ and $\mathrm{E}_{2}$, but no effect was observed with LH. The maturation rates were significantly increased when $\mathrm{FSH}, \mathrm{LH}$, and $\mathrm{E}_{2}\left(\mathrm{G}_{9}\right)$ containing media were additionally supplemented with KP $\left(\mathrm{G}_{10}\right)$.
\end{abstract}

Conclusion: This study demonstrated that the addition of $\mathrm{KP}(10 \mu \mathrm{g} / \mathrm{ml})$ to the $\mathrm{FSH}, \mathrm{LH}$, and $\mathrm{E}_{2}$ supplemented media would enhance the sheep oocyte maturation in vitro.

Keywords: kisspeptin, in vitro maturation, sheep oocytes.

\section{Introduction}

Gonadotropin-releasing hormone $(\mathrm{GnRH})$ has been known to play a major role in the control of reproduction for the last 30 years, but the mechanisms involved in the secretion of GnRH at cellular and molecular level are not completely understood [1]. Recent developments in reproduction with the use of kisspeptin (KP) have opened a new vista to understand these regulatory mechanisms of GnRH secretion [2]. $\mathrm{KP}$ seems to be involved in the onset of puberty, initiation of the breeding season and the dynamic changes of follicle-stimulating hormone (FSH) and luteinizing hormone (LH) secretion during estrous cycle [3]. KP, first identified as a metastasis suppressor molecule, is the product of the gene Kiss-1, which

Copyright: Byri, et al. Open Access. This article is distributed under the terms of the Creative Commons Attribution 4.0 International License (http://creativecommons.org/licenses/by/4.0/), which permits unrestricted use, distribution, and reproduction in any medium, provided you give appropriate credit to the original author(s) and the source, provide a link to the Creative Commons license, and indicate if changes were made. The Creative Commons Public Domain Dedication waiver (http://creativecommons.org/ publicdomain/zero/1.0/) applies to the data made available in this article, unless otherwise stated. encodes a 145-amino acid peptide. It has biologically active peptides ranging from 10 to 54 amino acids in length [4]. Genes encoding KP (KISS1) and its receptors (KISS1R) have been documented in the ovaries of fish [5], hamsters [6], pigs and goats [7], primate, and human ovaries [8].

Administration of KP induces the secretion of gonadotropin hormones in many species such as pigs [9], bovines [10,11], ewes [12-14], goats [15], canines $[16,17]$, and women $[18,19]$. The ability of $\mathrm{KP}$ to induce ovulation following intravenous administration has been demonstrated in prepubertal ewe lambs [20] and anestrous ewes [21]. The presence of high concentrations of KP in the porcine follicular fluid than in serum (335 vs. $25 \mathrm{pg} / \mathrm{mL}$ ) and expression of KISS1Rs in oocytes and cumulus cells during in vitro maturation (IVM) pig oocytes supported the local involvement of KP on the development of oocytes within the follicle [22]. Apart from these in vivo studies, very few studies have also been conducted to see the effect of KP on IVM of oocytes. Supplementation of KP to maturation media has been reported to improve the efficiency of pig [22] and 
bovine [23] oocyte maturation in vitro, but there are no studies on IVM of sheep oocytes.

Therefore, taking into account the significance of KP in development of follicles, this study was undertaken to study the effect of KP on IVM of sheep oocytes.

\section{Materials and Methods}

\section{Ethical approval}

The experiments comply with guidelines laid down by the Institutional Ethical Committee.

\section{Chemicals and media}

All media, hormones, fetal bovine serum (FBS), and other chemicals were sourced from Sigma Chemical Co., USA, and plastic ware was from Nunc, Denmark, unless otherwise indicated. KP-10 (TyrAsn-Trp-Asn-Ser-Phe-Gly-Leu-Arg-Phe- $\mathrm{NH}_{2}$ ) was purchased from Auropeptides, Hyderabad, India. HEPES buffered tissue culture medium 199 supplemented with 10\% FBS (Handling medium) was used for washing and handling of oocytes. Heparin (25 IU $/ \mathrm{ml})$ was additionally added to the handling medium for collection of oocytes. Bicarbonate buffered tissue culture medium 199 (TCM199B) supplemented with gentamicin $(50 \mu \mathrm{g} / \mathrm{ml})$ was used as control medium for maturation of oocytes. The media used for transport and washing of ovaries, collection, handling, and maturation of oocytes were supplemented with gentamicin $(50 \mu \mathrm{g} / \mathrm{ml})$ and filter sterilized $(0.22 \mu \mathrm{m})$ before use. Handling, collection, and maturation media were equilibrated with $5 \%$ carbon dioxide in air, in a humidified atmosphere at $38.5^{\circ} \mathrm{C}$ for at least $2 \mathrm{~h}$ before use.

\section{Collection and IVM of oocytes}

Collection and processing of ovaries for aspiration of cumulus oocyte complexes (COCs) were carried out as described by Arunakumari et al. [24,25]. Briefly, sheep ovaries were collected from a local slaughterhouse and transported to the laboratory in Dulbecco's phosphate buffered saline (D-PBS, Gibco, BRL, USA) maintained at $35^{\circ} \mathrm{C}$, within $2 \mathrm{~h}$ after collection. Each ovary was trimmed off adjacent fat and ligaments. External surface of the each ovary was sterilized by rinsing once in $70 \%$ alcohol and thrice in D-PBS. COCs were aspirated aseptically from the visible follicles ( $>6 \mathrm{~mm}$ diameter) using a $20 \mathrm{G}$ needle attached to $5 \mathrm{ml}$ disposable syringe containing $2 \mathrm{ml}$ of collection medium. COCs with homogeneous cytoplasm surrounded by at least three layers of compact cumulus cells were selected for IVM. The selected COCs were washed extensively in handling medium followed by respective IVM media. Subsequently, the 8-10 COCs were transferred into $50 \mu$ droplets of different IVM media in $35 \mathrm{~mm}$ culture dishes. The droplets were overlaid with autoclaved pre-equilibrated mineral oil. The dishes with COCs were cultured in an incubator with $5 \% \mathrm{CO}_{2}$ under humidified air at $38.5^{\circ} \mathrm{C}$ for $24 \mathrm{~h}$.

\section{Evaluation of oocytes following IVM}

At the end of IVM, the COCs were examined for cumulus cell expansion (CCE). The cumulus cells were removed by incubating them with $100 \mathrm{IU} / \mathrm{ml}$ of hyaluronidase for $15 \mathrm{~min}$ at $37^{\circ} \mathrm{C}$ and repeatedly passing them through a fire polished narrow bore glass capillary. The denuded oocytes were examined under an inverted microscope (TH4-200, Olympus, Japan) for the presence of the $1^{\text {st }}$ polar body (PB) in the perivitelline space.

\section{Experimental design}

Two separate experiments were designed. In the first experiment, influence of KP on IVM of the sheep COCs was investigated by supplementing the control medium with 5,10 and $15 \mu \mathrm{g} / \mathrm{ml}$ of KP. After determining the best concentration of KP, the effect of KP with different hormones was investigated in the second experiment (Table-1).

\section{Statistical analysis}

The proportion of oocytes exhibiting CCE and extrusion of PB were analyzed by ANOVA followed by Duncan's multiple range test using SPSS software version 16.0 (SPSS Inc., USA) and presented as the mean \pm standard error.

\section{Results}

In experiment 1, the proportion of COCs showing CCE in all three KP supplemented groups was similar

Table-1: Components of IVM media used in the experiment 2.

\begin{tabular}{lcl}
\hline S. No. IVM media groups & Composition of different IVM media \\
\hline 1 & $\mathrm{G}_{1}$ & Control medium: TCM $199 \mathrm{~B}+\mathrm{Gentamicin}(50 \mu \mathrm{g} / \mathrm{ml})$ \\
2 & $\mathrm{G}_{2}$ & Control medium $+\mathrm{KP}: 10 \mu \mathrm{g} / \mathrm{ml}$ \\
3 & $\mathrm{G}_{3}$ & Control medium $\mathrm{FSH}: 10 \mu \mathrm{g} / \mathrm{ml}$ \\
4 & $\mathrm{G}_{4}$ & Control medium $+\mathrm{FSH}(10 \mu \mathrm{g} / \mathrm{ml})+\mathrm{KP}(10 \mu \mathrm{g} / \mathrm{ml})$ \\
5 & $\mathrm{G}_{5}$ & Control medium $\mathrm{LH}: 10 \mu \mathrm{g} / \mathrm{ml}$ \\
6 & $\mathrm{G}_{6}$ & Control medium $+\mathrm{LH}(10 \mu \mathrm{g} / \mathrm{ml})+\mathrm{KP}(10 \mu \mathrm{g} / \mathrm{ml})$ \\
7 & $\mathrm{G}_{7}$ & Control medium $+\mathrm{E} 2: 1 \mu \mathrm{g} / \mathrm{ml}$ \\
8 & $\mathrm{G}_{8}$ & Control medium $+\mathrm{E} 2(1 \mu \mathrm{gl})+\mathrm{KP}(10 \mu \mathrm{g} / \mathrm{ml})$ \\
9 & $\mathrm{G}_{9}$ & Control medium $+\mathrm{FSH}(10 \mu \mathrm{g} / \mathrm{ml})+\mathrm{LH}(10 \mu \mathrm{g} / \mathrm{ml})+\mathrm{E}_{2}(1 \mu \mathrm{g} / \mathrm{ml})$ \\
10 & $\mathrm{G}_{10}$ & Control medium $+\mathrm{FSH}(10 \mu \mathrm{g} / \mathrm{ml})+\mathrm{LH}(10 \mu \mathrm{gl})+\mathrm{E}_{2}(1 \mu \mathrm{g} / \mathrm{ml})+\mathrm{KP}(10 \mu \mathrm{g} / \mathrm{ml})$ \\
11 & $\mathrm{G}_{11}$ & Control medium $+\mathrm{FSH}(10 \mu \mathrm{g} / \mathrm{ml})+\mathrm{LH}(10 \mu \mathrm{g} / \mathrm{ml})+\mathrm{E}_{2}(1 \mu \mathrm{g} / \mathrm{ml})+\mathrm{FBS}(10 \%)$ \\
12 & $\mathrm{G}_{12}$ & Control medium $+\mathrm{FSH}(10 \mu \mathrm{g} / \mathrm{ml})+\mathrm{LH}(10 \mu \mathrm{g} / \mathrm{ml})+\mathrm{E}_{2}(1 \mu \mathrm{g} / \mathrm{ml})+\mathrm{FBS}(10 \%)+\mathrm{KP}(10 \mu \mathrm{g} / \mathrm{ml})$ \\
\hline
\end{tabular}

IVM=In vitro maturation, $\mathrm{KP}=$ Kisspeptin, $\mathrm{FSH}=$ Follicle stimulating hormone, $\mathrm{LH}=$ Luteinizing hormone, $\mathrm{E}_{2}=$ Estradiol, FBS $=$ Fetal bovine serum 
to control, but the proportion of oocytes that extruded PB was significantly higher in KP supplemented media than in control medium (Table-2). Among the KP supplemented groups, the proportion of oocytes that extruded PB was significantly higher when COCs were cultured in the medium supplemented with $10 \mu \mathrm{g} / \mathrm{ml}$ of KP.

KP did not show any additional effect on CCE when $\mathrm{KP}$ was added to $\mathrm{FSH}, \mathrm{LH}$, and $\mathrm{E}_{2}$ supplemented $\left(\mathrm{G}_{4}, \mathrm{G}_{6}\right.$, and $\mathrm{G}_{10}$, respectively) and $\mathrm{FSH}+\mathrm{LH}+\mathrm{E}_{2}+\mathrm{FBS}$ $\left(\mathrm{G}_{12}\right)$ media (Table-3). However, the proportion of COCs exhibiting CCE was significantly increased when KP was added to $\mathrm{E}_{2}$ supplemented medium. The number of oocytes that extruded $\mathrm{PB}$ was significantly increased when KP was added to FSH, $\mathrm{E}_{2}, \mathrm{FSH}+\mathrm{LH}+\mathrm{E}_{2}$, and $\mathrm{FSH}+\mathrm{LH}+\mathrm{E}_{2}+\mathrm{FBS}$ supplemented media $\left(\hat{G}_{4}, G_{8}, G_{10}\right.$, and $G_{12}$, respectively). Interestingly, KP did not enhance the PB extrusion, in combination with $\mathrm{LH}\left(\mathrm{G}_{6}\right)$.

\section{Discussion}

This study has demonstrated for the first time that addition of $\mathrm{KP}$ to $\mathrm{FSH}, \mathrm{LH}, \mathrm{E}_{2}$ supplemented media can significantly increase the maturation rates of sheep oocytes in vitro. In experiment 1, TCM-199B was supplemented with $0,5,10,15 \mu \mathrm{g} / \mathrm{ml}$ of $\mathrm{KP}$, to identify the best concentration to support oocyte maturation in terms of CCE and extrusion of the $1^{\text {st }} \mathrm{PB}$. In sheep, 8-20 $\mu \mathrm{g}$ of KP was infused to monitor FSH and LH hormones in earlier studies [20,21]. Based on the $\mathrm{CCE}$ and extrusion of $\mathrm{PB}, 10 \mu \mathrm{g} / \mathrm{ml}$ of KP supported better for IVM of sheep oocytes. Similar to the present findings, maturation rate was improved when the bovine oocytes were matured in TCM-199 supplemented with $10 \mathrm{nM}$ of $\mathrm{KP}(13 \mu \mathrm{g})$ [23]. In contrast, none of the pig oocytes extruded PB when maturation medium was supplemented with KP alone [22]. It is likely that the action of KP on cumulus cells and oocytes might be different from species to species. For example, in ovariectomized sheep, the increased $\mathrm{LH}$ response to KP administration was decreased by administration of KP antagonist (p234) [26], whereas in dogs it was not altered by KP antagonist (p271) [17]. In this study, the pattern of oocyte maturation significantly increased from 5 to $10 \mu \mathrm{g} / \mathrm{ml}$ and then decreased at $15 \mu \mathrm{g} / \mathrm{ml}$. In vivo secretion of LH in response to KP administration was found to vary with dose, breed and physiological status of animal [13-15,27].

The action of KP on maturation of oocytes in vitro is different to that from in vivo. In vivo, KP directly acts on hypothalamic neurons and results in release of $\mathrm{GnRH}$, followed by FSH and $\mathrm{LH}$, which are responsible for follicle growth and ovulation. The expression of GnRH $\alpha$ and $\mathrm{LH}$ on cumulus cells and oocytes during IVM of pig oocytes suggested that KP activates its subordinate $\mathrm{GnRH} \alpha$, thereby increasing LH synthesis, which in turn will affect oocyte maturation [22]. In this study, to see the effect of KP with $\mathrm{FSH}, \mathrm{LH}$, and $\mathrm{E}_{2}$ alone or in combination, the COCs were matured in different maturation media (experiment 2, Table-1). The addition of FSH, LH, and $\mathrm{E}_{2}$ to IVM medium has been shown to improve the maturation rates in sheep oocytes, but the role of each hormone is not clear [28-30]. The proportion of

Table-2: Effect of different concentrations of KP on in vitro maturation of sheep oocytes.

\begin{tabular}{lcccc}
\hline Groups & Concentration of KP & $\begin{array}{c}\text { Number of oocytes } \\
\text { (replicates) }\end{array}$ & Proportion of CCE & Proportion of extrusion of 1st PB \\
\hline $\mathrm{T}_{1}$ & Control (without KP) & $120(10)$ & $68.33 \pm 2.42^{\mathrm{a}}$ & $4.99 \pm 1.36^{\mathrm{a}}$ \\
$\mathrm{T}_{2}$ & $05 \mu \mathrm{g} / \mathrm{ml}$ & $120(10)$ & $73.33 \pm 1.67^{\mathrm{a}}$ & $11.67 \pm 1.84^{\mathrm{b}}$ \\
$\mathrm{T}_{3}$ & $10 \mu \mathrm{g} / \mathrm{ml}$ & $120(10)$ & $74.17 \pm 2.31^{\mathrm{a}}$ & $24.17 \pm 1.45^{\mathrm{c}}$ \\
$\mathrm{T}_{4}$ & $15 \mu \mathrm{g} / \mathrm{ml}$ & $120(10)$ & $71.67 \pm 1.84^{\mathrm{a}}$ & $18.33 \pm 1.11^{\mathrm{d}}$ \\
\hline
\end{tabular}

Means with different superscripts, within a column, are significantly different. One-way ANOVA followed by Duncan's multiple range test $(\mathrm{p}<0.05) . \mathrm{KP}=$ Kisspeptin, $\mathrm{CCE}=$ Cumulus cell expansion, $\mathrm{PB}=$ Polar body

Table-3: Effect of $\mathrm{KP}$ in combination with $\mathrm{FSH}, \mathrm{LH}$, and $\mathrm{E}_{2}$ on in vitro maturation of sheep oocytes.

\begin{tabular}{|c|c|c|c|c|}
\hline Groups & Combinations & $\begin{array}{c}\text { Number of oocytes } \\
\text { (replicates) }\end{array}$ & Proportion of CCE & Proportion of extrusion of $1^{\text {st }}$ PB \\
\hline $\mathrm{G}_{1}$ & Control & $120(6)$ & $69.17 \pm 2.71^{b}$ & $6.67 \pm 1.05^{a}$ \\
\hline $\mathrm{G}_{2}$ & $\mathrm{KP}-10$ & $120(6)$ & $76.67 \pm 2.47 c$ & $26.67 \pm 2.11^{b}$ \\
\hline $\mathrm{G}_{3}$ & $\mathrm{FSH}$ & $120(6)$ & $91.67 \pm 1.67^{\mathrm{e}}$ & $54.17 \pm 2.71^{c}$ \\
\hline $\mathrm{G}_{4}$ & $\mathrm{FSH}+\mathrm{KP}$ & $120(6)$ & $94.17 \pm 0.83^{\mathrm{ef}}$ & $69.17 \pm 3.27^{\mathrm{e}}$ \\
\hline $\mathrm{G}_{5}$ & $\mathrm{LH}$ & $120(6)$ & $84.17 \pm 1.54^{d}$ & $58.33 \pm 4.01^{\mathrm{cd}}$ \\
\hline $\mathrm{G}_{6}$ & $\mathrm{LH}+\mathrm{KP}$ & $120(6)$ & $89.17 \pm 3.00^{\mathrm{de}}$ & $64.17 \pm 3.01^{\text {de }}$ \\
\hline $\mathrm{G}_{7}$ & $\mathrm{E}_{2}$ & $120(6)$ & $52.50 \pm 2.14^{a}$ & $31.67 \pm 2.11^{\mathrm{b}}$ \\
\hline $\mathrm{G}_{8}$ & $\mathrm{E}_{2}+\mathrm{KP}$ & $120(6)$ & $67.50 \pm 1.71^{\mathrm{b}}$ & $59.17 \pm 2.39^{c d}$ \\
\hline $\mathrm{G}_{9}$ & $\mathrm{FSH}+\mathrm{LH}+\mathrm{E}_{2}$ & $120(6)$ & $90.83 \pm 2.01^{\mathrm{e}}$ & $60.01 \pm 2.58^{\mathrm{cd}}$ \\
\hline $\mathrm{G}_{10}$ & $\mathrm{FSH}+\mathrm{LH}+\mathrm{E}_{2}^{2}+\mathrm{KP}$ & $120(6)$ & $95.01 \pm 0.01^{\mathrm{ef}}$ & $70.01 \pm 1.29 \mathrm{e}$ \\
\hline $\mathrm{G}_{11}$ & $\mathrm{FSH}+\mathrm{LH}+\mathrm{E}_{2}+\mathrm{FBS}$ & $120(6)$ & $95.01 \pm 0.01^{\text {ef }}$ & $80.00 \pm 1.29^{f}$ \\
\hline $\mathrm{G}_{12}$ & $\mathrm{FSH}+\mathrm{LH}+\mathrm{E}_{2}+\mathrm{FBS}+\mathrm{KP}$ & $120(6)$ & $98.33 \pm 1.05^{f}$ & $89.17 \pm 2.38^{9}$ \\
\hline
\end{tabular}

Means with different superscripts, within a column, are significantly different. One-way ANOVA followed by Duncan's multiple range test $(\mathrm{p}<0.05)$. $\mathrm{FSH}=$ Follicle stimulating hormone, $\mathrm{LH}=$ Luteinizing hormone, $\mathrm{E}_{2}=\mathrm{Estradiol}_{1} \mathrm{KP}=\mathrm{Kisspeptin}$, $\mathrm{CCE}=$ Cumulus cell expansion, $\mathrm{PB}=$ Polar body, FBS=Fetal bovine serum 
oocytes matured in medium supplemented with KP alone $\left(\mathrm{G}_{2}\right)$ was significantly lower than that of FSH, $\mathrm{LH}$, and $\mathrm{E}_{2}$ supplemented groups $\left(\mathrm{G}_{3}, \mathrm{G}_{5}, \mathrm{G}_{7}\right.$, and $\left.\mathrm{G}_{9}\right)$. In contrast, the bovine oocyte maturation rates in KP supplemented media was similar to that supplementing with FSH and FBS [23]. In this study, the addition of KP to FSH $\left(G_{4}\right)$ and $E_{2}\left(G_{8}\right)$ supplemented media significantly enhanced extrusion of $\mathrm{PB}$, compared to the media containing FSH or $\mathrm{E}_{2}$ alone, whereas no improvement was observed in LH and KP combination $\left(\mathrm{G}_{6}\right)$ (Table-3). It has been reported that priming of FSH is essential for the action of KP on IVM of pig oocytes. KP alone did not support extrusion of $\mathrm{PB}$ $(0 \%)$, but in combination with FSH $(76 \%)$ increased extrusion of PB [22]. Similarly, the addition of KP to the $\mathrm{E}_{2}$ supplemented medium appears to suppress the negative effect of $\mathrm{E}_{2}$ on nuclear maturation as shown in the pig [31].

The proportion of oocytes that showed CCE (95\%) and extrusion of PB (80\%) was significantly higher in standard $\mathrm{FSH}+\mathrm{LH}+\mathrm{E}_{2}+\mathrm{FBS}$ supplemented medium $\left(G_{11}\right)$ than control and other combinations $\left(\mathrm{G}_{2}-\mathrm{G}_{10}\right)$. This might be due to the presence of FBS in the maturation medium which provides nutrients, vitamins, and growth factors to the cells surrounding the oocyte and therefore plays an important role in the maturation of oocytes [32]. The maturation rates in IVM medium were on par with the maturation of earlier studies in sheep $[25,33,34]$. However, the addition of KP to the $\mathrm{FSH}+\mathrm{LH}+\mathrm{E}_{2}+\mathrm{FBS}$ supplemented medium $\left(\mathrm{G}_{12}\right)$ significantly increased the CCE (98\%) as well as PB extrusion (89\%) when compared to $\mathrm{FSH}+\mathrm{LH}+\mathrm{E}_{2}+\mathrm{FBS}\left(\mathrm{G}_{11}\right)$. The expression of KP receptors (KISS1Rs) in both oocytes and cumulus cells during IVM of pig oocytes and the increased maturation rates in FSH+KP supplemented media has been shown to be the result of the direct action of KP on oocytes and cumulus cells in an autocrine-paracrine fashion as in folliculogenesis [22]. Addition of various growth factors such as fibroblast growth factor-2, epidermal growth factor, insulin-like growth factor, insulin transferrin selenium, and growth hormone to IVM medium was also found to result in higher maturation and fertilization rates and improved embryo development in sheep oocytes [30,35-37]. Further, the combinations of these growth factors and hormones successfully supported in vitro culture of sheep PFs and yielded fertilizable oocytes $[24,38]$ and developed to morulae after IVM and fertilization [25], indicating the synergistic and direct action of hormones and growth factors on in vitro culture of sheep PFs and oocytes. The results of this study demonstrated the local interaction of $\mathrm{KP}$ with $\mathrm{FSH}$, and $\mathrm{E}_{2}$ during IVM of sheep oocytes as hypothesized in earlier studies [22] but it needs to be further explored by molecular approaches. The development competence of the oocytes matured in the presence of KP needs to be further evaluated by in vitro fertilization studies.

\section{Conclusion}

This study demonstrated that the addition of KP $(10 \mu \mathrm{g} / \mathrm{ml})$ to the $\mathrm{FSH}, \mathrm{E}_{2}, \mathrm{FSH}+\mathrm{LH}+\mathrm{E}_{2}$ supplemented media would enhance the sheep oocyte maturation in vitro. Addition of $\mathrm{KP}$ to $\mathrm{FSH}+\mathrm{LH}+\mathrm{E}_{2}+\mathrm{FBS}$ medium further increased the maturation rates in vitro.

\section{Authors' Contributions}

PB and AG: Conceived and designed the experiments, Performed the experiments. PB, AG, KRR and KBPR: Analysed the data, drafted and revised the manuscript. All authros have read and approved the final manuscript.

\section{Acknowledgments}

Department of Biotechnology (DBT), Government of India supported this work through a research grant (Proposal ID 12539) to Dr. G. Arunakumari. The authors are grateful to Dr. Daniel G. Miller, Former Assistant Professor, University of Minnesota, USA and Dr. Rao Dukkipati, Senior Lecturer in Animal breeding and Genetics, Massey University, New Zealand for critical review of the manuscript.

\section{Competing Interests}

The authors declare that they have no competing interests.

\section{References}

1. Caraty, A. and Franceschini, I. (2008) Basic aspects of the control of GnRH and LH secretions by kisspeptin: Potential applications for better control of fertility in females. Reprod. Domest. Anim., 43(S2): 172-178.

2. Daniel, J.A., Foradori, C.D., Whitlock, B.K. and Sartin, J.L. (2015) Reproduction and beyond, kisspeptin in ruminants. J. Anim. Sci. Biotechnol., 6: 23.

3. Decourt, C., Robert, V., Anger, K., Galibert, M., Madinier, J.B., Liu, X., Dardente, H., Lomet, D., Delmas, A.F., Caraty, A. and Herbison, A.E. (2016) A synthetic kisspeptin analog that triggers ovulation and advances puberty. Sci. Rep., 6: 26908.

4. Kotani, M., Detheux, M., Vandenbogaerde, A., Communi, D., Vanderwinden, J.M., Le Poul, E., Brézillon, S., Tyldesley, R., Suarez-Huerta, N., Vandeput, F., Blanpain, C., Schiffmann, S.N., Vassart, G. and Parmentier, M. (2001) The metastasis suppressor gene KiSS-1 encodes kisspeptins, the natural ligands of the orphan $\mathrm{G}$ protein-coupled receptor GPR54. J. Biol. Chem., 276: 34631-34636.

5. Filby, A.L., van Aerle, R., Duitman, J. and Tyler, C.R. (2008) The kisspeptin/gonadotrophin-releasing hormone pathway and molecular signaling of puberty in fish. Biol. Reprod., 78: 278-289.

6. Shahed, A. and Young, K.A. (2009) Differential ovarian expression of KiSS-1 and GPR-54 during the estrous cycle and photoperiod induced recrudescence in Siberian hamsters (Phodopus sungorus). Mol. Reprod. Dev., 76: 444-452.

7. Inoue, N., Hirano, T., Uenoyama, Y., Tsukamur, X., Okamura, H. and Maeda, K. (2009) Localization of kisspeptin and gonadotrophin releasing hormone $(\mathrm{GnRH})$ in developing ovarian follicles of pigs and goats. Biol. Reprod., 81: 551 .

8. Gaytan, F., Gaytan, M., Castellano, J.M., Romero, M., Roa, J., Aparicio, B., Garrido, N., Sanchez-Criado, J.E., Millar, R.P., Pellicer, A. and Fraser, H.M. (2009) KiSS-1 
in the mammalian ovary: Distribution of kisspeptin in human and marmoset and alterations in KiSS-1 mRNA levels in a rat model of ovulatory dysfunction. Am. J. Physiol. Endocrinol. Metab., 296(3): E520-E531.

9. Lents, C.A., Heidorn, N.L., Barb, C.R. and Ford, J.J. (2008) Central and peripheral administration of kisspeptin activates gonadotropin but not somatotropin secretion in prepubertal gilts. Reproduction, 135(6): 879-887.

10. Whitlock, B.K., Daniel, J.A., Wilborn, R.R., Maxwell, H.S., Steele, B.P. and Sartin, J.L. (2011) Effect of kisspeptin on regulation of growth hormone and luteinizing hormone in lactating dairy cows. J. Anim. Sci. Biotechnol., 2: 131-140.

11. Naniwa, Y., Nakatsukasa, K., Setsuda, S., Oishi, S., Fujii, N., Matsuda, F., Uenoyama, Y., Tsukamura, H., Maeda, K.I. and Ohkura, S. (2013) Effects of full-length kisspeptin administration on follicular development in Japanese Black beef cows. J. Reprod. Dev., 59(6): 588.

12. Pompolo, S., Pereira, A., Estrada, K. and Clarke, I. (2006) Colocalization of kisspeptin and gonadotropin-releasing hormone in the ovine brain. Endocrinology, 147: 804-810.

13. Arreguin-Arevalo, J.A., Lents, C.A., Farmerie, T.A., Nett, T.M. and Clay, C.M. (2007) KiSS-1 peptide induces release of LH by a direct effect on the hypothalamus of ovariectomized ewes. Anim. Reprod. Sci., 101: 265-275.

14. Wang, J., Sun, L., Zhang, T., Zhou, H. and Lou, Y. (2012) Effect of peripheral administration of kisspeptin-10 on dynamic LH secretion in prepubertal ewes. Asian Australas. J. Anim., 25(6): 785.

15. Hashizume, T., Saito, H., Sawada, T., Yaegashi, T., Ezzat,A.A., Sawai, K. and Yamashita, T. (2010) Characteristics of stimulation of gonadotropin secretion by kisspeptin-10 in female goats. Anim. Reprod. Sci., 118: 37-41.

16. Albers-Wolthers, K.H., deGier,J., Kooistra,H.S., Rutten, V.P., van Kooten, P.J., de Graaf, J.J., Leegwater, P.A., Millar, R.P. and Schaefers-Okkens, A.C. (2014) Identification of a novel kisspeptin with high gonadotrophin stimulatory activity in the dog. Neuroendocrinology, 99(3-4): 178-189.

17. Albers-Wolthers, C.H., de Gier, J., Rutten, V.P., van Kooten, P.J., Leegwater, P.A., Schaefers-Okkens, A.C. and Kooistra, H.S. (2016) The effects of kisspeptin agonist canine KP-10 and kisspeptin antagonist $\mathrm{p} 271$ on plasma LH concentrations during different stages of the estrous cycle and anestrus in the bitch. Theriogenology, 86(2): 589-595.

18. Dhillo, W.S., Chaudhri, O.B., Thompson, E.L., Murphy, K.G., Patterson, M., Ramachandran, R., Nijher, G.K., Amber, V., Kokkinos, A., Donaldson, M. and Ghatei, M.A. (2007) Kisspeptin-54 stimulates gonadotropin release most potently during the preovulatory phase of the menstrual cycle in women. J. Clin. Endocrinol. Metab., 92(10): 3958-3966.

19. Jayasena, C.N., Abbara, A., Comninos, A.N., Nijher, G.M., Christopoulos, G., Narayanaswamy, S., Izzi-Engbeaya, C., Sridharan, M., Mason, A.J., Warwick, J. and Ashby, D. (2014) Kisspeptin-54 triggers egg maturation in women undergoing in vitro fertilization. J. Clin. Invest., 124(8): 3667-3677.

20. Redmond, J.S., Macedo, G.G., Velez, I.C., Caraty, A., Williams, G.L. and Amstalden, M. (2011) Kisspeptin activates the hypothalamic-adenohypophyseal-gonadal axis in prepubertal ewe lambs. Reproduction, 141(4): 541-548.

21. Caraty, A., Smith, J.T., Lomet, D., Ben Said, S., Morrissey, A., Cognie, J., Doughton, B., Baril, G., Briant, C. and Clarke, I.J. (2007) Kisspeptin synchronizes preovulatory surges in cyclical ewes and causes ovulation in seasonally acyclic ewes. Endocrinology, 148(11): 5258-5267.

22. Saadeldin, I.M., Koo, O.J., Kang, J.T., Kwon, D.K., Park, S.J., Kim, S., Park, S.J., Kim, S.J., Moon, J.H., Hyun, J.O., Jang, G. and Lee, B.C. (2012) Paradoxical effects of kisspeptin: It enhances oocyte in vitro maturation but has an adverse impact on hatched blastocysts during in vitro culture. Reprod. Fertil. Dev., 24(5): 656-668.

23. Ming, H.E., Jun, W., Yu-Jiang, Y., Zi-Wei, L., Xun, L. and Wen-Fa, L. (2015) Expression and function of kisspeptin during bovine oocyte maturation in vitro. Chin. J. Anim. Sci., 11:5.

24. Arunakumari, G., Vagdevi, R., Rao, B.S., Naik, B.R., Naidu, K.S., Kumar, R.V.S. and Rao, V.H. (2007) Effect of hormones and growth factors on in vitro development of sheep pre antral follicles. Small Rumin. Res., 70: 93-100.

25. Arunakumari, G., Shanmugasundaram, N. and Rao, V.H. (2010) Development of morulae from the oocytes of cultured sheep pre antral follicles. Theriogenology, 74(5): 884-894.

26. Roseweir, A.K., Kauffman, A.S., Smith, J.T., Guerriero, K.A., Morgan, K., Pielecka-Fortuna, J., Pineda, R., Gottsch, M.L., Tena-Sempere, M., Moenter, S.M., Terasawa, E., Clarke, I.J., Steiner, R.A. and Millar, R.P. (2009) Discovery of potent kisspeptin antagonists delineates physiological mechanisms of gonadotropin regulation. J. Neurosci., 29: 3920-3929.

27. Tovar, S., Vázquez, M.J., Navarro, V.M., FernándezFernández, R., Castellano, J.M., Vigo, E., Roa, J., Casanueva, EF., Aguilar, E., Pinilla, L., Dieguez, C. and Tena-Sempere, M. (2006) Effects of single or repeated intravenous administration of kisspeptin upon dynamic LH secretion in conscious male rats. Endocrinology, 147: 2696-2704.

28. O'Brien, J.K., Rhodes, S.L., Maxwell, W.M.C. and Evans, G. (1994) Hormonal requirements for in vitro maturation of sheep oocytes. Theriogenology, 41(1): 266.

29. Accardo, C., Dattena, M., Pilichi, S., Mara, L., Chessa, B. and Cappai, P. (2004) Effect of recombinant human FSH and LH on in vitro maturation of sheep oocytes; Embryo development and viability. Anim. Reprod. Sci., 81: 77-86.

30. Guler, A.N., Poulin, P., Mermillod, M., Terqui, M. and Cognie, Y. (2000) Effect of growth factors, EGF and IGF-I, and estradiol on in vitro maturation of sheep oocytes. Theriogenology, 54: 209-218.

31. Bing, Y.Z., Naga, T. and Rodriguez-Martinez, H. (2001) Effects of cysteamine, FSH, and estradiol-17beta on in vitro maturation of porcine oocytes. Theriogenology, 55: 867-876.

32. Wani, N.A. (2002) In vitro maturation and in vitro fertilization of sheep oocytes. Small Rumin. Res., 44(2): 89-95.

33. Wani, N.A., Wani, G.M., Khan, M.Z. and Salahudin, S. (2000) Effect of oocyte harvesting techniques on in vitro maturation and in vitro fertilization in sheep. Small Rumin. Res., 36(1): 63-67.

34. Rao, B.S., Naidu, K.S., Amarnath, D., Vagdevi, R., Rao, A.S., Brahmaiah, K.V. and Rao, V.H. (2002) In vitro maturation of sheep oocytes in different media during breeding and non-breeding seasons. Small Rumin. Res., 43(1): 31-36.

35. Shirazi, A., Shams-Esfandabadi, N., Ahmadi, E. and Heidari, B. (2010) Effects of growth hormone on nuclear maturation of ovine oocytes and subsequent embryo development. Reprod. Domest. Anim., 45(3): 530-536.

36. Shabankareh, H.K., Sarsaifi, K. and Mehrannia, T. (2011) In vitro maturation of ovine oocytes using different maturation media: Effect of human menopausal serum. J. Assist. Reprod. Genet., 28(6): 531-537.

37. Mondal, S., Mor, A., Reddy, I.J., Nandi, S. and Parameswaragupta, P.S.P. (2015) Effect of fibroblast growth factor 2 (FGF2) and insulin transferrin selenium (ITS) on in vitro maturation, fertilization and embryo development in sheep. Braz. Arch. Biol., 58(4): 521-525.

38. Tamilmani, G., Rao, B.S., Vagdevi, R., Amarnath, D., Naik, B.R, Mutharao, M. and Rao, V.H. (2005) Nuclear maturation of oocytes in sheep preantral follicles cultured in vitro. Small Rumin. Res., 60: 295-305. 